PRINT ISSN 1119-8362

ELECTRONIC ISSN 1119-8362
Full-text Available Online at https://www.ajol.info/index.php/jasem

http://ww.bioline.org.br/ja
J. Appl. Sci. Environ. Manage.

Vol. 23 (3) 551-556 March 2019

\title{
Impact of Sawmill Industry on Maritime and Riparian Environments along Selected Rivers in Delta State, Nigeria
}

\author{
IGBEN, JL \\ Department of Environmental Management and Toxicology, Western Delta University, Oghara, Nigeria \\ Email; joma_igben@yahoo.com; Tel.:234 8034037691
}

\begin{abstract}
This study examines the spatial impact of sawmill industry on the maritime and riparian environments along selected rivers in Delta State, Nigeria and the resultant effects on inland fishing activities within the framework of Economic Adaptation theories of Population-Environment (P-E) inter-relationship. Primary data were collected from a questionnaire administered on 150 fishermen selected through an availability sampling technique in three settlements, drawn randomly from eight listed settlements engaged in both sawmill operations and fishing activities along the selected rivers. The questionnaire used for the study covered impact of sawmill operations on the maritime and riparian environments, and the indirect impacts on inland fishing. This was complemented by Focus Group Discussions (FGDs) with 15 fishermen in the selected settlements. The study revealed that sawmill operations resulted in the destruction of riparian vegetation, noise and air pollution, acceleration of weeds invasion, destruction of breeding grounds and general degradation of the riparian and maritime environments. These have indirect impact on inland fishing activities manifested in increased distance to points of fishing activity, frequent damages to nets, hooks and lines, decreased output, increased fishing hours and reduced fishing space in the study area. Impact evaluation of sawmill industry vis-à-vis inland fishing activities is recommended for sustainable development of the physical environment and fishing sector.
\end{abstract}

\section{DOI: https://dx.doi.org/10.4314/jasem.v23i3.27}

Copyright: Copyright ( $\odot 2019$ Igben. This is an open access article distributed under the Creative Commons Attribution License (CCL), which permits unrestricted use, distribution, and reproduction in any medium, provided the original work is properly cited.

Dates: Received: 17 November 2018; Revised: 19 January 2019; Accepted 22 January 2019

Keywords: Inland fishing, Sawmill industry, Environmental degradation, Riparian and Maritime environments,

Wood is an important resource obtained from forest ecosystems. The physical and mechanical transformation of wood into new products for man's use is carried out by forest enterprises. In Nigeria, these enterprises have been classified into formal and informal sectors. The former includes the organized wood-based industries such as sawmills, plywood mills, particle board mills and furniture factories while the latter comprises small forest-based operations without corporate identities and these include firewood, charcoal, chewing stick and sculptured wood items (GWVC, 1994). Furthermore, there is the preponderance of small forest-based operations in the country due to low technological level and the dominance of rural economy.

As profit-oriented, gross and productive enterprises utilizing raw materials from the forests, sawmills are usually located in the forest areas near sources of markets. This is because the lumber recovery rate in most sawmills varies between $50-55$ per cent. This means that between 50-55 per cent of logs put into sawmills end up as wood residues (Alviar, 1983; Fuwape, 1989, 1998). The residues generated in sawmills constitute solid waste in nature and they include wood barks, saw dust, wood shavings and trimmings. The methods of disposal of these residues lead to environmental pollution. For instance, saw dust are burnt in open air or are used to fill adjacent vegetated areas or banks of rivers; thereby increasing the temperature of surrounding water bodies and causing loss of biodiversity. Wood barks and trimmings are dumped into rivers or burnt indiscriminately in nearby bushes or used as fuel by residents of the area.

Usually, the siting of sawmills is preceded by the clearing of vegetation cover and sometimes sand filling of the area. This is followed by the erection of high-roof structures to house machines; the most common type of which is the CD horizontal saws use for the conversion of round logs into timber before transferring to smaller machines which saw timber into planks of various sizes. Also vertical staffs of hard wood are erected in open space near sawmills to stack products for sale and eventual evacuation by handpush carts, vans and Lorries to points of use. Roads may also be constructed to areas of sawmills to facilitate the evacuation of products. Thus, the siting and operations of sawmills impact negatively on the environment in several ways; pollution of water bodies, destruction of breeding grounds for fishes and other aquatic organisms such as mudskippers, snakes, crabs, and other reptiles; destruction of mangrove, 
raffia palm, and various species of trees, grasses and sedges and general degradation of the riparian environment.

In Delta State Nigeria, sawmills are located along river courses in the freshwater swamp and lowland rain forests particularly in the southern part dissected by numerous rivers, though a few of them are located in the uplands. The location of sawmills in the state is due to the presence of lumber trees such as mahogany (Khaya Spp), african walnut (Lovoa trichilioides), iroko (Chlorophora excelsa), abura (Mitragyna ciliata), sapele wood (Entandrophragma cylindricum), obeche (Triplochiton scleroxylon) and other hardwood species. In addition, the presence of rivers in the southern part of the state facilitates the transportation of $\operatorname{logs}$ to sawmill. Logs are usually transported through hand-dug canals to nearby streams from where they are fastened together into rafters and floated downstream to sawmill. However, in the hinterland, they are transported by Lorries (Igben and Ohiembor, 2015).

The digging of canals, floating of log rafters along river courses downstream and the operations of sawmills in the wetland environment affect inland fishing activities. Inland fishing in the area is done in rivers, streams and creeks using small hand-pulled canoes and various types and sizes of nets; gill nets, cast nets, dragnets in larger rivers and fish traps, spears, cages and baskets in smaller water bodies. Fishes caught include tilapia, mud fish, catfish, eel, prawns, shrimps, crayfish, lobsters, snakefish, and mollusks (periwinkle, oyster), and reptiles (turtles and river snakes). Thus, sawmill operations and inland fishing activities are carried out in the same geographic space or environment, consequently, the former indirectly impacts on the later.

This study is conceived within the broad framework of the economic adaptation theories of population and environment (P-E) inter-relationship championed by an economist, Julian Simon (1982), Ester Boserup (1965; 1970; 1981) and Kingsley Davis (1963). The central theme of these theories is that human beings adapt to the problems created by development efforts for most part smoothly and without grave setbacks. In the process of adaptation, they gain increased productivity and efficiency in the form of improved human welfare such as improved shelter, clothing and transportation. With regards to this study, the degradation of the riparian and maritime environments by sawmill operations creates problems for inland fishing activities and the workers in the sector devise strategies to surmount the problems in a bid to increase output to meet the demand of the teeming population. Some of these strategies, the theories contend, include intensification of fishing activities, probably embarking on fish farming, working longer hours and doing a second job and so on.

The literature is replete with studies on sawmill industry vis-à-vis the physical environment. (Arimoro et al, 2006; Ekpe et al, 2011; Elijah and Elegbede, 2012; Ogunbode et al, 2012; Pat-Mbano and Nkwocha, 2012; Adelegan et al, 2012). However, there is paucity of studies on the impact of sawmills on other human activities, including inland fishing. For instance, Olawuni and Okunola's (2014) study on the socio-economic impacts of sawmill industry on the residents of Ile-Ife in southwestern Nigeria shows that $61.7 \%$ of respondents living within a distance of 1$300 \mathrm{~m}$ in the study area earn below N5000.00 per month. The result of the Probit Model used in the analysis of data for the study shows that the sawmill industry in the area created significant impacts on job opportunity (0.63), domestic use for cooking (0.71), wood supply (0.58), and provision of infrastructure (0.63). The study concludes that sawmilling activities contribute significantly to the economic development of residents in the study area.

However, there has not been any known study on the impact of sawmill industry on the environment vis-à-vis inland on fishing activities in the riverine area of Delta State; hence, this study aims to identify the impact of sawmill industry on the maritime and riparian environments and analyse the resultant effect on inland fishing activities in the study area

\section{MATERIALS AND METHOD}

Study Area: Delta State lies roughly between Latitudes $5^{0} 00^{\prime}$ and $6^{0} 30^{\prime}$ north and Longitudes $5^{\circ} 00^{\prime}$ and $6^{0} 45^{\prime}$ east, over an area of 22,159 square kilometres, of which more than 60 per cent is land. The state is bordered in the north by Edo State, by Ondo State to the northwest, Anambra State to the east and Bayelsa State to the southeast. On its southern flank is the Bight of Benin, which covers approximately 160 kilometres of the state's coastline. The state is divided into twenty-five political divisions called Local Government Areas (LGAs). Delta State is generally a low-lying state, without remarkable hills, with an average elevation generally below 30 metres above sea level. The state has a deep coastal belt that is interlaced with rivulets and streams, which form the Niger Delta. The major rivulets and streams are in the western part; the big ones are Benin, Escravos, Warri, Ethiope, Jamieson, Forcados and Ramos, while River Niger is in the eastern flank. Virtually all the estuaries and rivers in the state flow into the Bight of Benin (Atlantic Ocean).

Delta State has a tropical climate characterized by uniformly high rainfall and temperature throughout the year, marked by two 
distinct seasons: the dry season and the rainy seasons. Temperatures are generally high throughout the year, with a mean of between $24^{0} \mathrm{C}\left(75.2^{\circ} \mathrm{F}\right)$ and $27^{\circ} \mathrm{C}$ $\left(80.4^{0} \mathrm{~F}\right)$. There is no significant variation between day and night temperatures (Udo, 1970). Furthermore, the state consists of four ecological zones, of coastal barrier island or ridges, mangroves, fresh water swamp forest and lowland rainforest. These zones were further classified by Ikporukpo (1996) into two; namely, the outer and inner delta. The outer delta composes muddy, sheltered creeks, deltas, brackish and a strong tidal waters characterized by mangrove (Rhizophora racemosa) as the most common plant. In this zone, the main occupations are inland fishing and trading. The inner delta is made up predominantly of swamp rain forest which is not as wet. The zone comprises wet lowland evergreen rainforests in the north and mangrove forests in the south. Associated with this zone are occupations such as farming, inland fishing, lumbering, hunting, trading and tapping of rubber trees and raffia palm. However, Igben et al (2014) divided the state into three ecological zones, namely, mangrove, freshwater swamp forest and the lowland rainforest. This division is based on the fact that the coastal barriers or ridges along the shore of the Atlantic Ocean are a transition zone containing little or no vegetation cover.

The population of Delta State in 2016 was $4,098,391$ persons, made up of 2,074,306 males and 2,024,085 females (NPC, 2006). Presently, the state has an estimated population of over 5 million in 2017 using the annual growth rate of 2.5 percent. The people of Delta State engage in a wide range of economic activities. These include farming, fishing mostly inland fishing, hunting, tapping of rubber, and raffia palm, mining, trading and manufacturing.

Research Design: The research design used in the study is descriptive in nature. This design involves no manipulation of variables rather only a description of variables and their relationship as they occur. In other words, the design is used to find the meaning and obtain understanding of the present condition through a careful and methodical observation of a particular event in the real world (Ogundipe et al, 2006). This design is deemed appropriate as the study seeks to analyse inland fishing activities as influenced by sawmills operation without manipulation of any of the variables.

Population and Sample: The target population for the study include workers engaged in inland fishing in areas where sawmills operations are carried out in Delta State. This definition therefore restricts the target population to riverine communities. A total of eight (8) settlements where both activities are carried out in the study area were identified, out of which three settlements were randomly selected with the aid of the table of Random Numbers. The selected settlements are Aladja, Koko and Burutu. Of the chosen settlements, Aladja is located along the Warri River in Udu LGA, Koko along the Benin River in Warri North LGA and Burutu along the Forcados River in Burutu LGA of the state as indicated in Figure 1.

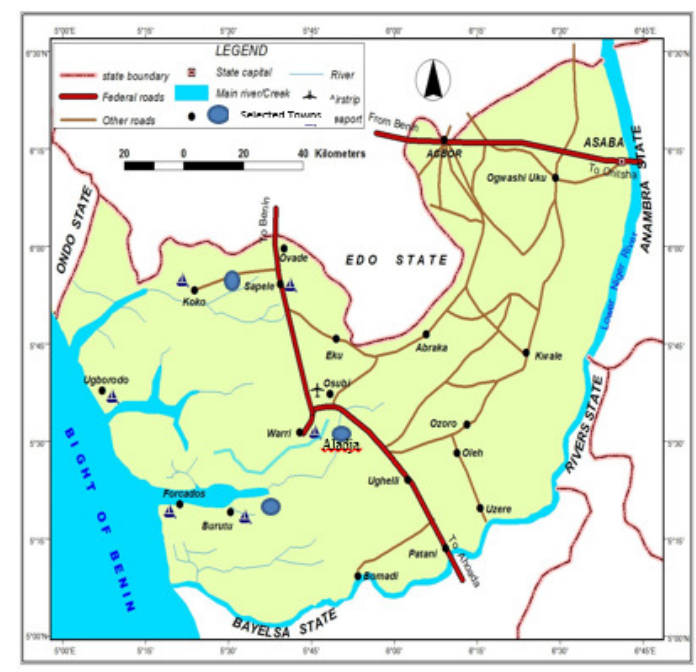

Fig 1: Map of Delta State showing Study Area

In each of the selected settlements, an availability sampling technique, which involves the identification and interviewing of fishermen and women, was done. A total of fifty (50) respondents were targeted and interviewed in each of the selected settlement via the use of well-structured questionnaires worded in line with the aim of the study. Thus a total of 150 respondents were interviewed. The questionnaire sought information on the nature of fishing activities as affected by sawmilling operations. It was structured in such a way that questions asked require respondents to answer either YES or NO. This was supplemented by Focus Group Discussions (FGDs) with five fishermen each from the selected settlements. Therefore, a total of fifteen (15) fishermen were engaged in Focus Group Discussions (FGDs). Data collected for the study were collated and condensed into manageable size and frequency of occurrence worked out and presented in tables. Simple percentages were used to analysed the distributions of events.

\section{RESULT AND DISCUSSION}

Age of sex characteristics of Respondents: The age and sex composition of the sampled population is presented in Table 1. Table 1 above shows the age and sex characteristics of fishermen in the three 
settlements sampled for this study. It reveals that a majority of 95 respondents representing $63.3 \%$ were males. Of this number, 79 respondents were above 40 years; with 25 respondents were between $41-50$ years, 32 respondents between 51-60 years and 10 respondents above 60 years. While 5 respondents were less than 20 years, 4 respondents and 10 respondents were in the age cohorts of 21-30 years and 31-40 years respectively. The age distribution of fisherwomen in the area was similar to those of fishermen with more than $50 \%$ above 40 years. In this category 14 respondents were within the age of 41-50 years, 11 respondents in the age group of 51-60 years and 8 respondents above 60 years. While 11 respondents were below 20 years, 10 respondents were between 21-30 years and 11 respondents between $31-40$ years. The implication of having a majority of the fishermen above 40 years is that adjustments or changes in occupation and perhaps fishing techniques and skills will be difficult if faced with problems that militate against their practice such as sawmill operations.

Impact of sawmills on marine and riparian environment: Table 2 below shows the various ways sawmill operations impact on the marine and riparian environment as perceived by the respondents interviewed in the three settlements sampled for this study.

Table 1: Age and Sex Compositions of Respondents in the study area

Table 1: Age and Sex Compositions of Respondents in the study area.
\begin{tabular}{|l|l|l|l|l|l|l|l|l|}
\hline & Male & \multicolumn{2}{l|}{ Female } & \multirow{2}{*}{ Total } & Percentage \\
\hline Age Group & Aladja & Koko & Burutu & Aladja & Koko & Burutu & & \\
\hline & & & & & & & & \\
$>20$ years & 2 & 0 & 3 & 4 & 4 & 3 & 16 & 10.7 \\
$21-30$ years & 1 & 2 & 1 & 3 & 6 & 1 & 14 & 9.3 \\
$31-40$ years & 3 & 4 & 3 & 5 & 3 & 3 & 21 & 14.0 \\
41-50 years & 8 & 10 & 7 & 6 & 4 & 4 & 39 & 26.0 \\
$51-60$ years & 10 & 11 & 10 & 3 & 5 & 3 & 42 & 28.0 \\
$<60$ years & 3 & 4 & 3 & 2 & 3 & 3 & 18 & 12.0 \\
\hline Total & 27 & 31 & 27 & 23 & 25 & 17 & 150 & 100.0 \\
\hline
\end{tabular}

Table 2: Impact of sawmills on the Environment

\begin{tabular}{|l|l|l|l|l|l|l|}
\hline S/N & Nature of impact & Aladja & Koko & Burutu & Total & Percentage \\
\hline 1. & Destruction of riparian vegetation & 43 & 34 & 41 & 118 & 78.6 \\
2. & Noise pollution & 36 & 39 & 43 & 118 & 78.6 \\
3. & Smoke/Air pollution & 45 & 38 & 44 & 127 & 84.6 \\
4 & Acceleration of weed invasion & 40 & 33 & 39 & 112 & 74.6 \\
5 & Flooding of adjacent land & 38 & 41 & 32 & 111 & 74.0 \\
6 & Obstruction to navigation & 39 & 28 & 36 & 103 & 68.6 \\
7. & Degradation of aesthetic beauty & 21 & 29 & 31 & 81 & 54.0 \\
8. & Water pollution & 41 & 39 & 44 & 124 & 82.6 \\
9. & Destruction of breeding grounds & 26 & 32 & 39 & 97 & 64.6 \\
10. & Degradation of surrounding land & 42 & 34 & 33 & 109 & 72.6 \\
\hline
\end{tabular}

Source: Fieldwork, 2017

Table 2 shows the responses of fishermen in the selected settlements to questions raised in the questionnaire on the items listed 1-10 above. On the destruction of the riparian environment by sawmill operations, a total of 118 respondents representing $78.6 \%$ of the 150 respondents were of the view that sawmill activities destroy the riparian vegetation. While 118 respondents $(78.6 \%)$ were also of the opinion that sawmilling activities lead to noise pollution of the environment, 127 respondents or $84.6 \%$ of the total respondents were of the view that their activities result in air pollution as a result of smoke emitted from burning of sawdust and other wood trimmings around premises of sawmills. The invasion of weeds, particularly water hyacinth (Eichhornia crassipes), during the raining season between May and November in the area, a period which also coincides with the floating of $\log$ rafter from the forests downstream, is also attributed to sawmill activities. To this opinion, 112 respondents (94.6\%) out of the total of 150 respondents agreed. While 111 respondents $(74.0 \%)$ and 103 respondents $(68.6 \%)$ respectively were in affirmative that sawmill activities degrade the aesthetic beauty of the environment and also obstruct navigation, a whopping 124 respondents, representing $82.6 \%$ were of the view that the sawmilling activities leads to water pollution. Focus Group Discussion (FGD) with fishermen lends credence to the fact that inland fishing is severely hindered in areas invaded by water hyacinth. A fisherman interviewed in Aladja community states, inter alia, "The weeds are usually brought to this area by the logs. When they arrive, they increase so rapidly that it is difficult to cut a way through them. Apart from obstructing canoeing, they make the casting of nets also impossible". The table also reveals that ninety 
(90) respondents representing $60.0 \%$ of the 150 respondents interviewed agreed that sawmill operations have increased hours of fishing. This is because fishing expeditions have to be taken to areas far away from sawmills in order to avoid some of the negative impacts of sawmill on inland fishing activities. Destruction of breeding grounds and degradation of surrounding land was attributed to sawmill activities by 97 respondents (64.6\%) and 109 respondents $(72.6 \%)$ respectively.

Effects of sawmill operation on fishing activities: Table 3 below shows the various ways fishing activities in the study area is impacted upon by sawmill activities as perceived by the respondents.

Table 3: Spatial Effects of sawmill operation in inland fishing activities.

\begin{tabular}{|l|l|l|l|l|l|l|}
\hline S/N & Nature of Effect & Aladja & Koko & Burutu & Total & Percentage \\
\hline 1 & Increased distance to point of activity & 47 & 36 & 43 & 126 & 84.0 \\
2. & Frequent damage to fishing instruments & 38 & 43 & 39 & 120 & 80.0 \\
3. & Decrease in output & 40 & 37 & 30 & 107 & 71.3 \\
4. & Increase in fishing hours & 29 & 33 & 28 & 90 & 60.0 \\
5. & Reduction in fishing space Source: Fieldwork, 2017 & 36 & 34 & 30 & 100 & 66.6 \\
\hline
\end{tabular}

Table 3 above reveals that a total of 126 respondents representing $84.0 \%$ were of the opinion that the location of sawmills in their areas of operation increased the distance to points of fishing. It implies that they have to move longer distance far into the river to carry out fishing activities. Corroborating their claim in a Focus Group Discussion, they attested that they have moved as far as $5 \mathrm{~km}$ away from saw mills to carry out their activities. Frequent damage to fishing tools such as nets, hooks, lines, and other fishing instruments was also identified as one of the effects of saw mills by 120 respondents $(80.0 \%)$. The respondents complained of floating and submerged pieces of woods that damage nets during fishing expedition. As one of the respondents in Burutu contended, "Sometimes, the presence of a submerged piece of wood in the water could be very deceitful. You may be thinking with high expectation that your net has caught a big fish only to find, on pulling out the net, that a piece of wood or log had not only caught the net but also tore it"

Corollary to the above is the problem of decrease in output. To this, 107 respondents representing 71.3\% were of the view that sawmill operations have resulted in decrease in output. The decrease may be the result of the disturbance of breeding grounds for fishes and the pollution of water bodies. It was gathered from the Focus Group Discussions that output from fishing had decreased drastically to the extent that some of the fishermen could no longer sustain their families and some had even left fishing for other occupations. Lastly, because both fishing and sawmill activities are carried out in the same geographic space, the spatial extent of inland fishing activities is reduced. A total of 100 respondents representing $66.6 \%$ were of the view that spaces for fishing is reduced as a result of sawmill operations, particularly by floating rafters waiting to be sawn into planks.
Conclusion: This paper reveals that the sawmill industry degrades the maritime and riparian environments and this indirectly impacts on inland fishing in the study. Increased distance to points of fishing activities, frequent damage to nets and other fishing tools, decreased output, increased in fishing hours and reduction in fishing spaces are some of the resultant impact of sawmills on inland fishing. The implication of these findings is that workers in the fishing sector have to move longer distances to their points of activities. Therefore, the study recommends that an Impact Evaluation (IE) should be carried out on sawmills, also Environmental Impact Assessment (EIA) study should be extended to the sawmill industries.

\section{REFERENCES}

Adelegun R.O.A., Berezi E.P. and Akintunde, O. A. (2012). Air pollution in a sawmill industry. The Okobaba (Ebute-Meta Lagos Experience). J. sustainable Dev. Environ. Protect. 2(2) 29.

Alviar, G.O. (1983). Sawmills industry in Nigeria. Field document No. 17 FAO. Rome 53pp.

Arimoro, F.O, IKomi, R.B, Osalor, E.C. (2006) Impact of sawmills waste on water quality and fish. Communities in Benin River, Niger Delta Area, Nigeria. World J. Zoo. 1(2) 94-102

Boserup, E. (1965). Conditions for agricultural growth. London, George Allen and Unwin.

Boserup, E. (1970). Women's role in economic development. London, George Allen and Unwin.

Boserup, E. (1981). Population and technology. Oxford, Basil Blackwell.

IGBEN, JL 
Ekpe, S, Adinya, I. B, Awoke, M. U., Ijoma, J. U, Edem, H. O. and Enum, E. E. (2011) Comparative study of the activities of sawmilling industry on the environment of two selected locations within southern Nigeria. Germany, GRIN Publishers.

Elijah, F.B,and Elegbede, 1. (2015). Environmental sustainability impact of Okobaba Sawmill Industry on some biogeochemical characteristics of the Lagos Lagoon. Poult Fish Wild. Sci. 3; 131

Davis, K. (1963). The theory of change and response in modern demographic history. Population Index Activities, 29 (4): 345-366.

Ehrlich, P.R. (1974). The population bomb. New York, Ballantine Books

Ehrlich, P.R. and Ehrlich, A.H. (1990). The population explosion. New York, Simon and Schuster.

Fuwape, J. A. (1989). An assessment of wood conversion efficiency in some sawmills in Ondo State. Nig. J. Forestry 20 (2) 56-63.

Fuwape, J. A. (1998). Development in wood-based industries in 44-48 Nigeria. Foresea Miyazaki, 26: $575-585$.

GWVC (1994). Review of the wood-based sector in Nigeria. Report presented to Forest Management. Evaluation and Coordinating Unit, Abuja 185pp.

Igben, J. L., Ihayere C. A. and Ohiembor, O. M. (2014). Spatial dynamics of fuel wood exploitation in Delta State, Nigeria. Ethiop. J. Environ. Stud. Manage. 7 (6): 628-634

Igben, J. L. and Ohiembor, O. M. (2015). Lumbering as a factor of deforestation in the Freshwater Swamp Forest in Delta State, Nigeria.
International Journal of Research in Agriculture and Forestry, 2(9):1-9

Ogunbode, EB, Fabunmi, F.O, Ibrahim, S.M, Jimoh I, O, and Idowu, O. (2013). Management of sawmill wasted in Nigeria. Case study of Minna, Nigeria State. Greener J. Sci. Engineer. Technol. Res. 3 (4) 127-134

Ogundipe, G. A. T., Lucas, E. O. and Sanni, A. I. (2006). Systematic collection of data. In: Olayinka, A. I. et al (eds). Methodology of Basic and Applied Research (2nd Edition). Ibadan, Post Graduate School, University of Ibadan. Pp. 95-111

Olawuni, P. O. and Okunola, O. H. (2014). Socioeconomic impacts of sawmill industry on residents: a case study of Ile-Ife, Nigeria. $J$. Econ. Dev. Stud. 2 (3):67-176

Pat-Mbano, EC, and Nkwocha, E.E, (2012) Assessment of impact of sawmill industry on ambient air quality at Utu community in Akwa1bom State, Nigeria. J.S.N, 3(1) 205-211

Simon, J.L. (1982). Answer to Malthus: Julian Simon interview by William Beckley. Population and Development Review, Vol. 8, No. 1.

Udo, R.K. (1970). Geographical regions of Nigeria. Berkeley and Los Angeles, University of California Press. 